\title{
Changes in Hepatic Nitrogen Balance in Plasma Concentrations of Amino Acids and Hormones and in Cell Volume after Overnight Fasting in Perinatal and Adult Rat
}

\author{
PIETJAN J. E. BLOMMAART, ROB CHARLES, ALFRED J. MEIJER, AND WOUTER H. LAMERS
}

\author{
Department of Anatomy and Embryology [P.J.E.B., R.C., W.H.L.] and E. C. Slater Institute for \\ Biochemical Research [P.J.E.B. A.J.M.], Academic Medical Centre, Department of Biochemistry, \\ University of Amsterdam, Amsterdam, The Netherlands
}

\section{ABSTRACT}

\begin{abstract}
Important regulatory factors of intrahepatic protein synthesis and proteolysis are amino acids, glucagon, insulin, and cell volume. We have investigated the changes in these factors with development and after an overnight fast and evaluated their contribution to changes in the hepatic nitrogen balance in vivo. In the fed state, glucagon levels were highest in suckling animals and gradually declined in older rats, whereas the concentration of insulin increased during development. The amino acid concentrations in liver and plasma declined during the suckling period to levels that in vitro are highly permissive for induction of autophagic proteolysis. In all age groups investigated, fasting was associated with a drop in hepatic protein content, together with a marked decrease in hepatocellular volume and insulin concentrations. On the other hand, glucagon concentrations and the concentration of many amino acids in plasma and liver
\end{abstract}

responded to fasting with a pronounced decrease in perinatal and suckling animals, but this response had become blunted at weaning and had disappeared in adult animals. These findings suggest that insulin and/or hepatocellular volume are more likely candidates as short-term physiologic regulators of the hepatic nitrogen balance than are glucagon or amino acids. In glucosesupplemented fetuses, high levels of insulin could not compensate for a decreased hepatocellular volume in averting a catabolic state, suggesting that cell volume is the more important factor. Although our study cannot discriminate between the effects of fasting on protein synthesis and degradation, our findings show unequivocally that, for a rapid growth of the liver, suckling animals have to be fed around-the-clock. (Pediatr Res 38: 10181025, 1995)
The cellular protein content is regulated by modulation of the rates of synthesis and/or degradation. The nutritional and hormonal status have been shown to be of paramount importance as modulators of the rate of synthesis and degradation of proteins in the liver (1-7). In vivo studies in which the effect of refeeding after prolonged periods of starvation (2-5 d) was studied (8-10) and in vitro studies with perfused livers (cf. Ref. 1), freshly isolated $(6,7,11,12)$ or cultured hepatocytes (13-15) have identified amino acids and the hormones insulin and glucagon as major determinants of hepatic lysosomal proteolysis and protein synthesis. High ambient concentrations of amino acids and insulin suppress intrahepatic proteolysis (1, $6,7)$ and stimulate protein synthesis $(16-19)$, whereas glucagon exerts the opposite effect $(1,13,14,20)$. More recently, it

Received October 31, 1994; accepted May 16, 1995.

Corresponding and reprint requests: W. H.. Lamers, M.D., Ph.D., Academic Medical Centre, University of Amsterdam, Department of Anatomy and Embryology, Meibergdreef 15, 1105 AZ Amsterdam, The Netherlands.

Supported in part by grant 900-528-050 from the Netherlands Organization for Scientific Research (NWO). was proposed that lysosomal proteolysis in rat liver is also regulated by changes in the volume of the hepatocyte, an increase in cell volume being inhibitory $(21,22)$. As indicated, most of these findings were obtained from in vitro studies, involving strong manipulation of the nutritional and hormonal environment of the hepatocytes. In this respect, we had previously observed in cultured hepatocytes that intrahepatic lysosomal proteolysis in the perinatal period is sensitive to changes in the concentrations of amino acids, but not yet to cAMP (13). Furthermore, we found in these cultures that there is a direct relation between ambient amino acids and the rate of protein synthesis (Blommaart PJE, Meijer AJ, Lamers WH, manuscript submitted for publication). As far as we know, no concerted study has been carried out to obtain information on whether and to what extent each of these parameters (concentrations of circulating and intracellular amino acids, insulin, and glucagon and the volume of the hepatocyte) change in vivo upon a more physiologic stimulus, such as an overnight fasting period. Because the combination of a high rate of synthesis together with a suppressed rate of proteolysis in the liver is 
unique for the suckling period and has been held responsible for the rapid postnatal growth of the liver (23), we wanted to evaluate whether the developmental changes in the (plasma) concentrations of amino acids, insulin and glucagon, and changes in hepatocellular volume were as would be anticipated if they are responsible for the low rate of proteolysis in the liver of suckling animals compared with the adult. The present study was therefore undertaken to assess whether and to what extent each of the above-mentioned factors can contribute to the nitrogen balance of the liver after an overnight fast in the developing and adult rat.

\section{METHODS}

\section{Animals}

Wistar rats were obtained from the HSD animal farm in Zeist (The Netherlands). Water and food were available ad libitum. A 12-h light cycle (0800 to $2000 \mathrm{~h}$ ) was used. Fetal age was determined by dated matings. Postnatal age was determined from the day of birth $(=\mathrm{d} 0)$, which usually occurred at the beginning of $d 22$ of pregnancy. Pups were weaned at $3 \mathrm{wk}$.

Twenty-one-day-old fetuses were delivered by caesarian section. After ligation of the umbilical cord, the placenta was removed and fetuses were directly decapitated and liver and plasma samples were obtained, or fetuses were kept in a humidity crib at $37^{\circ} \mathrm{C}$. Fetuses younger than $21 \mathrm{~d}$ of gestation are not viable ex utero. In one group of fetuses glucose was administered by s.c. injection of $50 \mu \mathrm{L}$ of $0.5 \mathrm{M}$ glucose at zero time, followed by $50 \mu \mathrm{L}$ every $90 \mathrm{~min}$ (in the text referred as "supplemented with glucose" or "glucose-supplemented"), whereas in another group no glucose was administered. The fetuses were moistened and activated every $20 \mathrm{~min}$. After 11 and $24 \mathrm{~h}$ the fetuses were decapitated and plasma and liver samples were obtained.

Seven-day-old suckling, 20-d-old weanling, and male adult (2-3 mo) rats were starved overnight (1600 to 1000), with water available ad libitum. During starvation, suckling and weanling rats were kept in a humidity crib at $30^{\circ} \mathrm{C}$, whereas fed sucklings and weanlings were left with their mothers. For suckling and weanling animals no distinctions was made for sex. Fed male adult rats eat $20-25 \mathrm{~g} \cdot \mathrm{d}^{-1}$ (AM-II standard diet, Hope-Farms BV, The Netherlands).

Animal welfare was in accordance with institutional guidelines of the University of Amsterdam.

\section{Determination of the Concentrations of Amino acids}

Liver. After anesthetization as described elsewhere (13), 19and 21-d-old fetal, 7-d-old suckling, 20-d-old weanling, and adult rats were bled by decapitation. The liver was quickly removed and frozen in liquid nitrogen. Subsequently, the liver was pulverized under liquid nitrogen, and liver protein was precipitated by adding 3 volumes of $4 \%$ (wt/vol) ice-cold sulfosalicylic acid and $10 \mathrm{mM} N$-ethylmaleimide. The latter compound was added to form an adduct with reduced glutathione, because the retention times of reduced glutathione and of aspartate on the amino acid analyzer were identical under our experimental conditions. The supernatants were brought to
$\mathrm{pH} 11$ with $3 \mathrm{M} \mathrm{LiOH}$ to complete the formation of the adduct. Subsequently, samples were brought to $\mathrm{pH} 2.2$ with $40 \%$ sulfosalicylic acid and amino acids were determined on a LKB $\alpha$-plus amino acid analyzer as described for extracts from cultured hepatocytes (13). For liver samples, the detection limit of the amino acid analyzer was $50 \mathrm{nmol} \cdot \mathrm{g}$ of liver wet weight $^{-1}$. To examine to what extent contamination with blood interferes with the determination, livers from 20 -d-old weanling rats were also flushed by perfusion for $1 \mathrm{~min}\left(3 \mathrm{~mL} \cdot \mathrm{min}^{-1}\right)$ with modified Krebs-Henseleit bicarbonate medium $\left(0^{\circ} \mathrm{C}\right)$. No differences in hepatic amino acid concentrations were found between the two procedures. Adult rat livers were always flushed.

Plasma. Fetuses 19 and $21 \mathrm{~d}$ old (with placenta) were removed from the uterus, and blood from three to seven fetuses was obtained by decapitation. In fetuses, blood could be collected only from the caval vein. Blood was obtained from 7-d-old suckling rats from the portal or inferior caval vein of different animals, whereas in the case of 20-d-old weanling and adult rats, blood was obtained from the portal and inferior caval vein of the same animal. The blood was quickly transferred into EGTA-coated tubes $\left(0^{\circ} \mathrm{C}\right)$. After removal of the erythrocytes by centrifugation $\left(10 \mathrm{~min}\right.$ at $\left.800 \times \mathrm{g}, 0^{\circ} \mathrm{C}\right)$, plasma proteins were precipitated by adding ice-cold sulfosalicylic acid (final concentration $8 \%\left(\mathrm{wt} / \mathrm{vol}\right.$ ); overnight, $4^{\circ} \mathrm{C}$ ), and samples of the supernatant were brought to $\mathrm{pH} 2.2$ with 3 $\mathrm{M} \mathrm{LiOH}$. Amino acids were determined as described elsewhere (13). For plasma samples, the detection limit of the amino acid analyzer was $5 \mathrm{nmol} \cdot \mathrm{mL}$ of plasma $^{-1}$.

\section{Determination of the Glucose Concentration in Plasma}

Glucose was determined in an aliquot of the plasma samples obtained for the determination of the amino acid concentrations. Plasma proteins were precipitated by adding ice-cold perchloric acid [final concentration, 5\% (wt/vol); overnight, $\left.4^{\circ} \mathrm{C}\right]$, and samples of the supernatant were brought to $\mathrm{pH} 7.0$ with a mixture of $2 \mathrm{M} \mathrm{KOH}$ and $0.3 \mathrm{M} 3$-morpholinopropanesulfonic acid. Glucose was measured spectrophotometrically as previously described (24).

\section{Determination of the Glycogen Content}

The glycogen content of the liver was measured essentially as described by Lust et al. (25), with the following modifications. Samples of livers were extracted in $0.1 \mathrm{M} \mathrm{KOH}(50 \mathrm{mg}$ wet weight $\cdot \mathrm{mL}^{-1}$ ), heated for $45 \mathrm{~min}$ at $85^{\circ} \mathrm{C}$ to destroy glucose, cooled, and acidified to $\mathrm{pH} 4.5$ with $3 \mathrm{M}$ acetic acid. After removal of the precipitated protein by centrifugation $\left(5-10 \mathrm{~min}\right.$ at $\left.10^{4} \times \mathrm{g}, 4^{\circ} \mathrm{C}\right)$, glycogen present in $100-\mu \mathrm{L}$ aliquots was digested with $0.14 \mathrm{U}$ of amyloglucosidase (Boehringer $\mathrm{GmbH}$, Mannheim) for $2 \mathrm{~h}$ at $40^{\circ} \mathrm{C}$. Subsequently, the glucose formed was measured fluorimetrically as described elsewhere (26). Background glucose was measured in identically treated samples except that amyloglucosidase was omitted. 


\section{Determination of the Protein and DNA Content}

The protein content of the liver was determined by homogenizing the liver in $0.25 \mathrm{M}$ sucrose supplemented with $0.1 \%$ (vol/vol) Triton X-100 (100 mg wet weight $\cdot \mathrm{mL}^{-1}$ ) and assaying an aliquot of the homogenate with the enhanced protocol of the bicinchoninic acid (BCA protein assay reagent (Pierce, Rockford, IL). BSA was used as a standard. The DNA content was determined in the same samples with the diphenylamine method (27). Herring sperm DNA was used as a standard.

\section{Determination of Insulin and Glucagon}

Caval and portal blood was collected as described above, except that tubes containing heparin (Venoject, Terumo Europe N.V.; 15 U.S.P.U. per $\mathrm{mL}$ ) and aprotonin (Trasylol, Bayer; 1000 K.I.U. per $\mathrm{mL}$ ) were used to prevent blood clotting and degradation of the hormones, respectively. Insulin and glucagon were measured by RIA, using ${ }^{125}$ I-labeled rat insulin and porcine glucagon as probes, according to the procedures outlined by the manufacturers (Incstar Corporation and Byk-Sangtec Diagnostica GmbH \& Co. KG, respectively). Rat insulin and porcine glucagon were used as standards. Rat and porcine glucagon have identical amino acid sequences (28).

\section{Statistical Analysis}

Statistical significance of differences in parameter values was determined with the unpaired $t$ test using a two-tailed analysis.

\section{RESULTS}

To facilitate the comparison of different developmental stages, age-related changes in a particular metabolic parameter and the response to fasting are grouped together in the figures. To provide a background for the observed physiologic responses to a short-term fast, we will first describe the developmental changes in the different parameters and compare them with literature for validation. Thereafter, the response of the respective parameters to fasting will be described per age group to highlight the characteristics of the metabolic state of the animals.

\section{Development}

Total liver wet weight and total liver protein content increased 45- and 95-fold, respectively, between $1 \mathrm{~d}$ before birth and the adult stage (Fig. 1, $A$ and $B$ ). Total liver DNA content (Fig. 1C) increased only 25 -fold. Dividing liver wet weight by the DNA content of the liver provided an approximation of liver cell volume (Fig. 1D). The data (Fig. 1D) revealed a 50\% decrease in the average cell volume between $1 \mathrm{~d}$ before and 7 $\mathrm{d}$ after birth. After this initial postnatal decrease, which was previously shown to occur within a few hours after birth (29-31), there was an almost 4-fold increase in average liver cell volume in the period between $7 \mathrm{~d}$ after birth and the adult stage. Dividing liver protein content by liver DNA content (Fig. 1, $B$ and $C$ ) revealed that the changes in hepatocellular
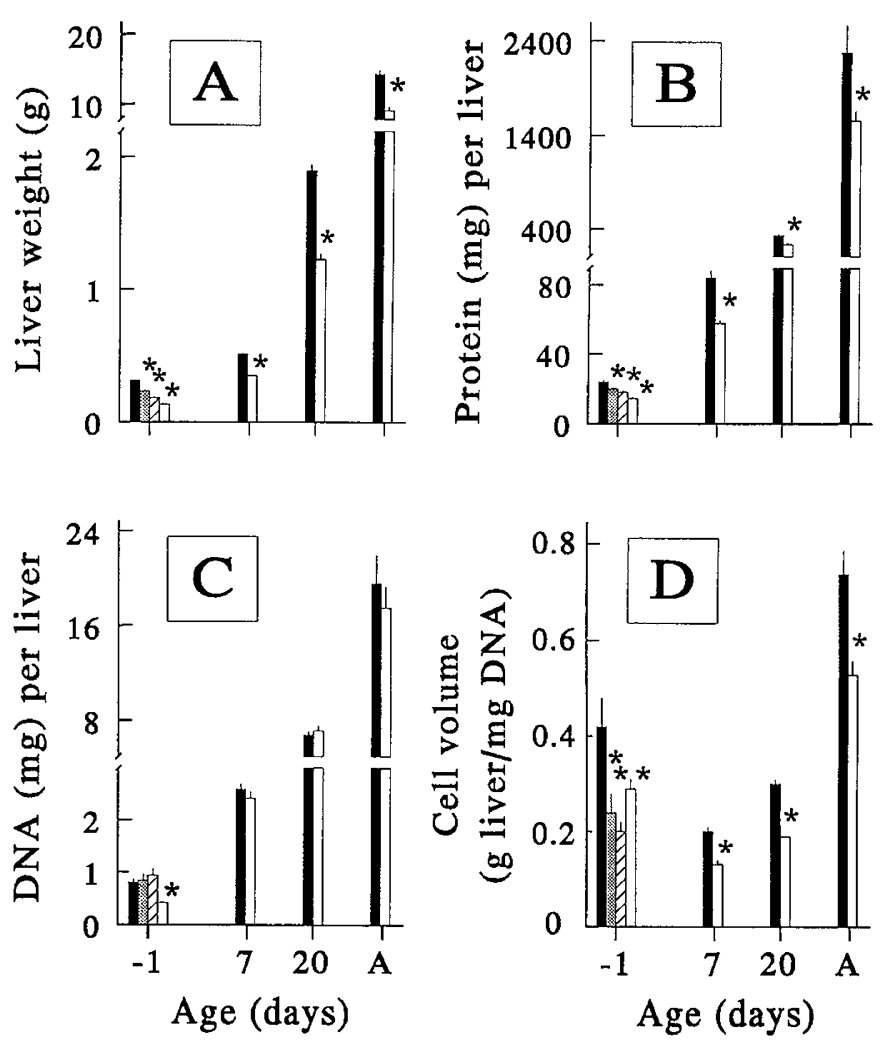

Figure 1. Effect of fasting on hepatic protein and DNA content and the volume of the hepatocytes. Effect of a short-term fast on total liver wet weight $(A)$, total liver protein content $(B)$, total liver DNA content $(C)$, and the volume of the hepatocytes $(D)$ in 21 -d-old fetal $(-1$, i.e. $1 \mathrm{~d}$ before birth), 7-d-old suckling (7), 20-d-old weanling (20), and adult $(A)$ rats. Parameter values of newly delivered or fed rats are depicted in black bars, overnight fasted rats in white bars, fetuses injected with glucose in gray bars, and values of fetuses fasted for $11 \mathrm{~h}$ in hatched bars. Results shown are the means ( $\pm \mathrm{SE}$ ) of samples from 5 to 25 different livers. Significantly different from the fed state, $*_{p}<$ 0.05 .

volume are accompanied by similar changes in cellular protein content.

The glycogen content of the liver (Fig. $2 A$ ) is approximately 5 -fold higher in the late fetal period than at any time during postnatal life and rapidly drops after birth $(32,33)$. At $7 \mathrm{~d}$ after birth, the glycogen content of the liver has not yet reached the adult level, probably because of the high contribution of fat in the diet (milk). Plasma glucose concentration increased gradually during development (Fig. 2, $B$ and $C$ ), in agreement with data from the literature (34).

Glucagon levels in portal plasma are much higher in suckling rats than in either fetal, weanling or adult rats (Fig. 3A), whereas the developmental changes in plasma insulin levels showed, compared with glucagon, a virtually reciprocal pattern (Fig. $3 B$ ). These observations agree very well with data from previous studies (33-35). In the adult, portal insulin levels were 3 -fold higher than caval insulin levels $(p<0.05)$, whereas glucagon levels were not significantly different. In suckling and weanling animals, the hormone concentrations in portal and caval plasma were similar (Fig. 3, $A$ and $B$ ).

The decline with development in amino acid concentrations (Fig. 4) in plasma confirm data from the literature (36), although these authors did not notice the relation between cir- 


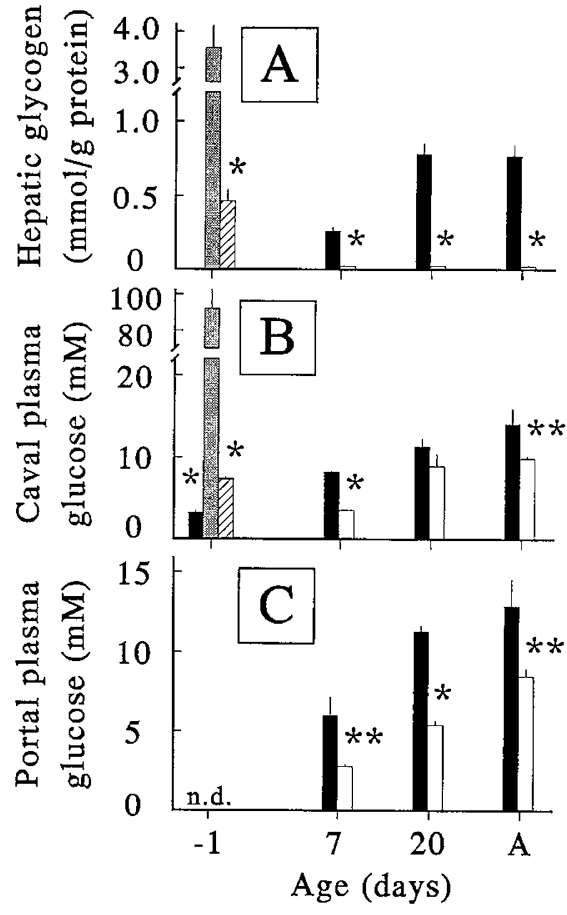

Figure 2. Effect of fasting on hepatic glycogen content and plasma glucose levels. Effect of a short-term fast on the glycogen content of the liver $(A)$ and on caval $(B)$, and portal $(C)$ plasma glucose concentrations in 21-d-old fetal $(-1$, i.e. $1 \mathrm{~d}$ before birth), 7-d-old suckling (7), 20-d-old weanling (20), and adult $(A)$ rats. Parameter values of newly delivered or fed rats are depicted in black bars, overnight fasted rats in white bars, fetuses injected with glucose in gray bars, and values of fetuses fasted for $11 \mathrm{~h}$ in hatched bars. Glycogen was measured as glycosyl glucose as described under "Experimental Procedures" and expressed as millimoles of glycosyl glucose $g$ of liver protein ${ }^{-1}$. Results shown are the means ( $\pm S E$ ) of four to eight livers and three to four blood samples of different animals. Each fetal blood sample consists of four to five fetuses. Significantly different from the fed state (for fetuses, significantly different from glucose-fed animals); ${ }^{*} p<0.05 ; * * 0.05<p<0.01 ; n . d$, no data.

culating concentrations of amino acids and their membrane transport mechanisms. The observed changes in liver strongly resemble those found previously by us in cultured hepatocytes (13). During development, the concentrations of Asp, Glu, Asn, Gln, Ala, Gly, Ser, and Thr, amino acids that are transported into the hepatocytes by sodium-dependent systems (3739), remained severalfold higher in the hepatocytes than in either portal or caval plasma. The plasma concentrations of these amino acids were comparable in the portal and caval vein, and generally did not change during development, with the exception of Asp and Glu which decreased. The intrahepatic concentrations of these amino acids generally decreased, in agreement with a developmental decrease in the activity of the sodium-dependent transport systems in hepatocytes (4043), combined with an increase in hepatic amino acid catabolism ( $c f$. Ref. 44). An exception was Gly, the intrahepatic concentration of which only transiently decreased in the suckling rat. The concentrations of Met, Ile, Leu, Val, Lys, Phe, Tyr, and Met, amino acids that are transported into the hepatocytes by a sodium-independent, nonconcentrative transport system (37-39), decreased $50-75 \%$ from fetal to adult stage and were similar in liver and plasma of the postnatal animals.

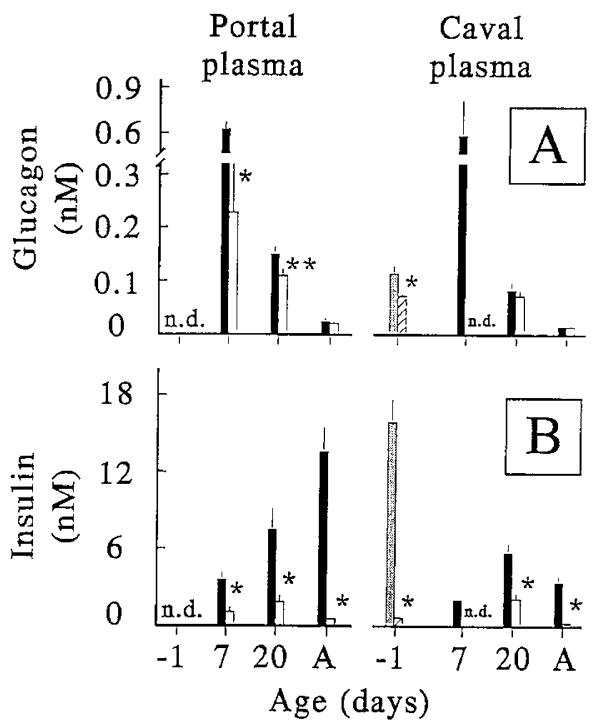

Figure 3. Effect of fasting on plasma glucagon and insulin levels. Effect of a short-term fast on the glucagon $(A)$ and insulin $(B)$ concentrations in plasma of 21-d-old fetal ( -1 , i.e. $1 \mathrm{~d}$ before birth), 7-d-old suckling (7), 20-d-old weanling $(20)$, and adult $(A)$ rats. Parameter values of fed rats are depicted in black bars, overnight fasted rats in white bars, fetuses injected with glucose in gray bars, and values of fetuses fasted for $11 \mathrm{~h}$ in hatched bars. Results shown are the means ( $\pm S E$ ) from three to seven different samples, except for the portal insulin concentration value of 7-d-old suckling rats, of which only two samples were available and for which the range is given. Each fetal blood sample consists of six fetuses; each suckling blood sample consists of two to four pups; each weanling blood sample consists of one animal; from each adult rat both caval and portal blood samples were taken. Significantly different from the fed state (for fetuses, significantly different from glucose-fed animals), ${ }^{*} p<0.05 ; * * 0.05<p<0.1 ;$ n.d., no data.

Sodium-independent transport of amino acids into hepatocytes has been reported not to change with development (41).

\section{Effects of Short-Term Starvation}

Twenty-one-day-old fetal rats. To be able to distinguish between insulin and cell volume changes as factors contributing to changes in the hepatic nitrogen balance, glucose was administered to one group of fetuses (referred as "glucosesupplemented"). In these animals cell shrinkage occurred despite high levels of insulin (see below).

In glucose-supplemented animals, liver wet weight had decreased $25 \%$ and liver protein content $15 \%$ at $11 \mathrm{~h}$ after caesarian section (Fig. 1, $A$ and $B$ ). Natural birth is associated with a similar decrease in liver wet weight (30-32) and in total protein content (calculations from Refs. 29-32 and 45). In the 11-h fasted pups (i.e. nonsupplemented pups), liver wet weight decreased an additional 20\% relative to the glucosesupplemented controls, whereas the protein content of the liver decreased an additional 10\% (not significant). Taking into account that glycogen accumulates $2.4 \mathrm{~mL}$ of water per $\mathrm{g}(46$, 47), one can calculate that $3.5 \mathrm{mmol}$ of glycosyl glucose $\mathrm{g}$ of protein $^{-1}$ (Fig. 2A) corresponds, at a protein content of 87 $\mathrm{mg} \cdot \mathrm{g}$ of liver wet weight ${ }^{-1}$, with $185 \mathrm{mg} \cdot \mathrm{g}$ of liver wet weight $^{-1}$ (i.e. nearly $20 \%$ of the liver wet weight). Therefore, the loss of glycogen in the liver of the fasted pup accounts for the decrease in liver wet weight and in cell volume upon fasting (Fig. 1D). We can similarly calculate that $65-75 \%$ of 


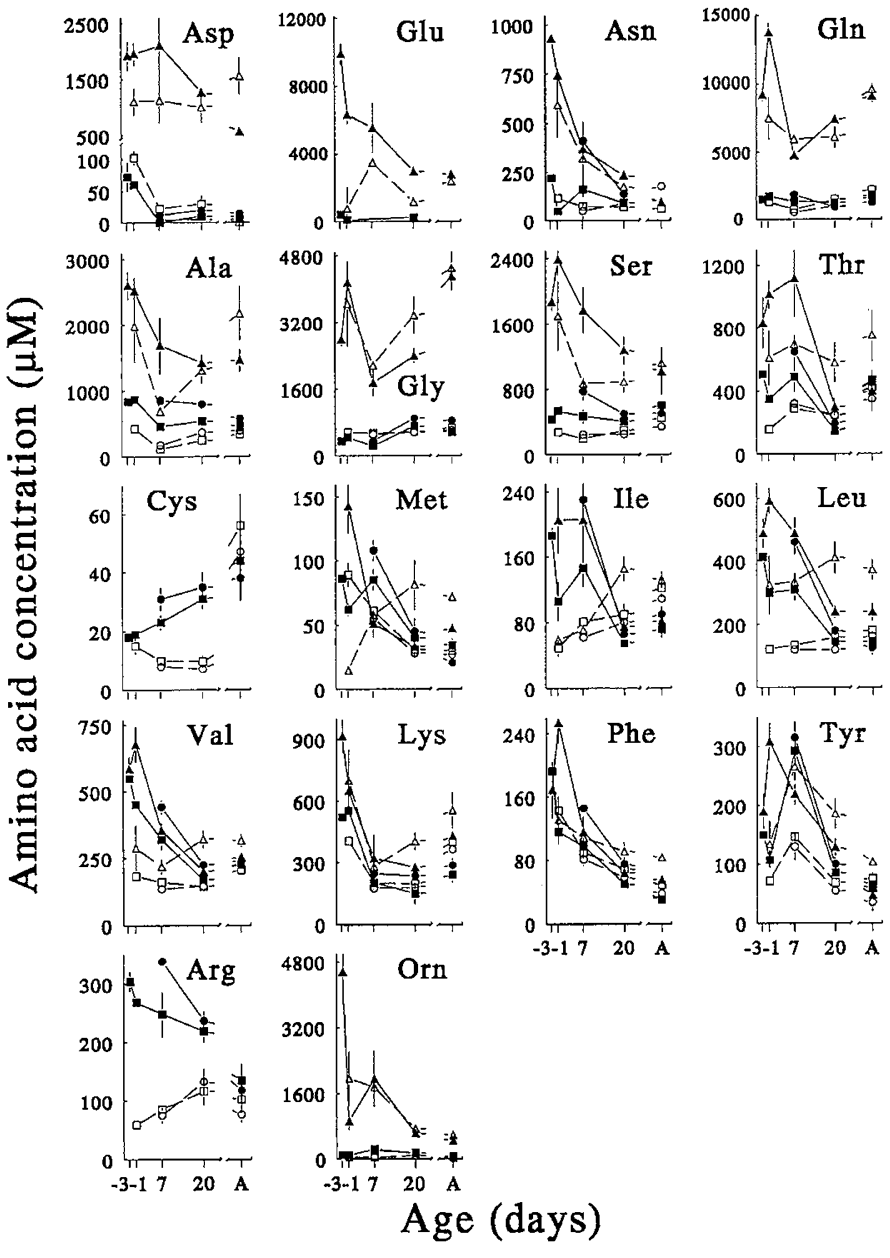

Figure 4. Effect of fasting on plasma and hepatic amino acid concentrations. Effect of a short-term fast on the amino acid concentrations in liver (nanomoles'g of liver wet weight ${ }^{-1}$, triangles), portal plasma (nanomoles $\cdot \mathrm{mL}$ of plasma ${ }^{-1}$, circles), and caval plasma (nanomoles $\mathrm{mL}$ of plasma $^{-1}$, squares) of 19-d-old ( -3 , i.e. $3 \mathrm{~d}$ before birth), 21-d-old fetal (-1), 7-d-old suckling (7), 20 -d-old weanling (20), and adult $(A)$ rats. Fetal rats delivered by caesarian section were fasted for $11 \mathrm{~h}$, and postnatal animals were fasted overnight. Parameter values of newly delivered or fed rats are depicted in black symbols and those of fasted rats in white symbols. Results shown are the means $( \pm \mathrm{SE})$ of samples from three to six different rats. Each fetal blood sample consists of four to five fetuses. Note the different scales on the $y$ axis.

the decrease in liver wet weight after natural birth is due to the loss of glycogen and protein $(29-32,45)$. Therefore, the $25 \%$ decrease in cell volume in glucose-supplemented fetuses, relative to the fetuses taken directly after caesarian section, occurs also after natural birth. Liver DNA (Fig. 1C) did not decrease during the first $11 \mathrm{~h}$ of fasting in these animals, but decreased to almost $50 \%$ during an additional $13 \mathrm{~h}$ of fasting. After studying histologic sections of these livers (not shown), we conclude that this disappearance of DNA from the fetal liver can be attributed to a selective loss of nonhepatocytic cells. These cells have also been shown to disappear from the fetal liver under conditions simulating stress (31). The 24-h fasted animals also showed a pronounced additional loss of liver wet weight (30\%; Fig. 1A) and protein content (20\%; Fig. 1B), compared with the 11-h fasted pups.

In the fasted fetuses concentrations of circulating glucose were much lower than in the glucose-supplemented fetuses
(Fig. 2B). Compared with glucose-supplemented fetuses, the levels of circulating glucagon decreased $35 \%$ in 11 -h fasted animals, whereas insulin levels decreased to less than $7 \%$ of control (Fig. 3, $A$ and $B$ ). These changes in glucose, glucagon, and insulin concur with previously published data obtained in fasted newborns (33). In liver and plasma the amino acid concentrations in the glucose-supplemented and 11-h fasted fetuses were comparable, but, with the exception of Orn, lower than directly after caesarian section (Table 1). The decrease in plasma amino acid concentrations in 11-h fasted animals is in agreement with the data from Girard et. al. (48) obtained in 16-h fasted newborns.

Seven-day-old suckling rats. In suckling rats a $30 \%$ decrease in liver wet weight and total liver protein was observed after an overnight fast (Fig. 1, $A$ and $B$ ). The liver DNA content in the fed state was slightly higher than in the fasted state ( $p=$ 0.05) (Fig. 1C). The decrease in cell volume was 30\% (Fig. $1 D$ ). Glycogen virtually disappeared from the liver (Fig. $2 A$ ), whereas the concentration of circulating glucose (Fig. 2, $B$ and $C)$ decreased $50 \%$. Glucagon and insulin concentrations (Fig. $3, A$ and $B$; portal plasma) both decreased $70 \%$ upon fasting. No changes were observed in the intrahepatic concentrations of Asn, Gly, Met, Lys, Phe, Tyr, and Orn after starvation, whereas the concentrations of Asp, Glu, Ala, Ser, Thr, Ile, Leu, and Val decreased 40-50\% (Fig. 4). The response of the plasma concentrations in portal and caval blood of 7-d-old suckling rats to fasting was generally similar to that in fetal rats, decreasing approximately $50-70 \%$ (Fig. 4). Remarkably, the concentration of Gln increased after starvation, whereas the portal and caval concentrations of Gly and Lys and the caval concentration of Phe hardly changed or even increased (Fig. 4).

Twenty-day-old weanling rats. Liver wet weight and total liver protein content decreased 35 and $30 \%$, respectively, after a short-term starvation (Fig. 1, $A$ and $B$ ), whereas total liver DNA content did not change (Fig. $1 C$ ), so that the average volume of the hepatocytes decreased $35 \%$ (Fig. 1D). As in suckling rats, glycogen disappeared almost completely from the liver (Fig. $2 A$ ). Concentrations of circulating glucose decreased $50 \%$ after an overnight fast (Fig. 2, $B$ and $C$ ). At the same time, glucagon levels did not change, whereas insulin levels decreased (Fig. 3, $A$ and $B$ ). In Fig. 4 it is shown that the amino acid concentrations in liver were similar or higher in the fasted than in the fed state, except for Glu the concentration of which decreased $60 \%$. In portal and caval plasma the concentrations of Ala, Cys, Ser, Arg, and Orn decreased 40-50\%, whereas no changes were observed in the concentrations of the other amino acids after a short-term fast.

Adult rats. In adult rats, liver wet weight and total liver protein content had decreased approximately 35 and $30 \%$, respectively, after an overnight fast (Fig. 1, $A$ and $B$ ). These data are in agreement with previous cytophotometric and biochemical data (49-51). No significant changes were found in total liver DNA content after fasting (Fig. $1 \mathrm{C}$ ), so that the volume of the hepatocytes decreased 35\% (Fig. 1D). After fasting, the glycogen content of the liver was extremely low (Fig. 2A). The caval and portal glucose concentration decreased 30-35\% after fasting. (Fig. 2, $B$ and $C$ ). The level of glucagon did not change, whereas the level of insulin de- 
Table 1. Amino acid concentrations in liver and in caval plasma of 21 -d-old fetal rats

\begin{tabular}{|c|c|c|c|c|c|c|}
\hline \multirow[b]{3}{*}{ Amino acid } & \multicolumn{6}{|c|}{ Concentration $(\mu \mathrm{M})$} \\
\hline & \multicolumn{2}{|c|}{ Start } & \multicolumn{2}{|c|}{ Glucose-supplemented } & \multicolumn{2}{|c|}{ Fasted } \\
\hline & Liver & Plasma & Liver & Plasma & Liver & Plasma \\
\hline Asp & $1948 \pm 206$ & $60 \pm 4$ & $1019 \pm 303$ & $58 \pm 15$ & $1105 \pm 234$ & $103 \pm 11$ \\
\hline Glu & $6339 \pm 514$ & $101 \pm 1$ & $3794 \pm 878$ & $160 \pm 24$ & $4441 \pm 1245$ & ND \\
\hline Asn & $745 \pm 35$ & $49 \pm 12$ & $121 \pm 5$ & $42 \pm 8$ & $594 \pm 166$ & $116 \pm 19$ \\
\hline Gln & $13746 \pm 690$ & $1727 \pm 75$ & $2838 \pm 921$ & $876 \pm 252$ & $7506 \pm 1525$ & $1348 \pm 28$ \\
\hline Ala & $2519 \pm 202$ & $871 \pm 41$ & $1948 \pm 515$ & $510 \pm 188$ & $1981 \pm 545$ & $428 \pm 34$ \\
\hline Gly & $4163 \pm 340$ & $448 \pm 40$ & $3198 \pm 848$ & $504 \pm 132$ & $3825 \pm 1032$ & $507 \pm 28$ \\
\hline Ser & $2389 \pm 187$ & $541 \pm 32$ & $1573 \pm 353$ & $199 \pm 53$ & $1700 \pm 420$ & $280 \pm 25$ \\
\hline Thr & $1016 \pm 91$ & $352 \pm 32$ & $346 \pm 103$ & $133 \pm 39$ & $612 \pm 172$ & $157 \pm 18$ \\
\hline Cys & ND & $19 \pm 1$ & ND & $10 \pm 3$ & ND & $15 \pm 3$ \\
\hline Met & $143 \pm 22$ & $62 \pm 5$ & $57 \pm 39$ & $45 \pm 14$ & $19 \pm 5$ & $89 \pm 9$ \\
\hline Ile & $205 \pm 40$ & $106 \pm 23$ & ND & $31 \pm 26$ & ND & $49 \pm 10$ \\
\hline Leu & $592 \pm 41$ & $308 \pm 15$ & $193 \pm 60$ & $103 \pm 42$ & $308 \pm 91$ & $122 \pm 10$ \\
\hline Val & $678 \pm 66$ & $452 \pm 14$ & $193 \pm 53$ & $202 \pm 76$ & $289 \pm 84$ & $183 \pm 19$ \\
\hline Lys & $661 \pm 71$ & $554 \pm 15$ & $456 \pm 71$ & $326 \pm 22$ & $673 \pm 152$ & $405 \pm 11$ \\
\hline Phe & $254 \pm 25$ & $116 \pm 12$ & $90 \pm 20$ & $92 \pm 18$ & $131 \pm 30$ & $143 \pm 13$ \\
\hline Tyr & $309 \pm 32$ & $107 \pm 11$ & $88 \pm 15$ & $76 \pm 25$ & $134 \pm 40$ & $72 \pm 5$ \\
\hline $\operatorname{Arg}$ & ND & $268 \pm 6$ & ND & $25 \pm 11$ & ND & $59 \pm 9$ \\
\hline Orn & $916 \pm 213$ & $88 \pm 14$ & $1320 \pm 431$ & $22 \pm 6$ & $1962 \pm 647$ & $50 \pm 6$ \\
\hline
\end{tabular}

Twenty-day-old fetal rats were delivered by caesarian section. Blood and liver samples were obtained from fetuses directly after delivery (Start), after injection with glucose as described under "Experimental Procedures" (Glucose-supplemented) or after $11 \mathrm{~h}$ of fasting (Fasted). Results shown are the means ( \pm SE) of three to six liver or blood samples. Each blood sample consists of four to five fetuses. ND, not detectable.

creased to $10 \%$ of that in fed rats (Fig. 3). Figure 4 shows that the amino acid concentrations in liver and in plasma of adult rats were similar or higher in the fasted than in the fed state, as was observed earlier for arterial amino acid concentrations in rat (52) and for portal and hepatic concentrations in rabbit (53).

\section{DISCUSSION}

The rat is a species that continues to grow during its entire lifespan, although the rate of growth of the body, including that of the liver, continuously declines (32). Previous investigations have shown that the initially rapid growth of the liver not only results from a high rate of protein synthesis, but also from a low rate of protein degradation during the suckling period (23). Intrahepatic protein synthesis and degradation are known to be controlled by amino acids, insulin, and glucagon ( $c f$. Refs. 1 and 12$)$ and changes in cell volume $(21,22,54)$. To explore the role of each of these factors in the regulation of the protein balance during the neonatal growth phase of the liver, we have investigated the changes in the hepatic nitrogen balance, the plasma concentrations of amino acids, insulin, and glucagon, and the hepatocellular volume in perinatal, suckling, weanling, and adult animals after an overnight fast as a short-term physiologic stimulus for protein catabolism.

In the fed state, a considerable developmental decline was seen in the amino acid concentrations in liver and plasma, the concentrations of circulating amino acids being 2-4-fold higher in fetal than in adult rats. The developmental decline in the levels of circulating amino acids observed in vivo gradually takes the concentrations of amino acids into a range that, in vitro (13), is highly permissive for the induction of autophagic proteolysis by changes in, for example, the concentrations of insulin and/or glucagon (22). In the fed state, the developmental changes in the plasma levels of insulin and glucagon were reciprocal. Glucagon levels were highest in the suckling animal and gradually declined in older rats. High levels of glucagon were shown to enhance the uptake of amino acids by the liver, resulting in increased glucose production (55). The high levels of glucagon in the suckling period may, therefore, accommodate for the enhanced production of glucose from amino acids, that compensate for the low intake of carbohydrates via the milk. In agreement with the high concentration of glucagon, cAMP concentrations in the liver are relatively high during the suckling period $(34,35)$. Although a high ambient concentration of glucagon and a high intracellular concentration of cAMP are associated with a stimulation of proteolysis in adult hepatocytes $(1,4,56)$, we have found that a high intracellular level of cAMP cannot yet stimulate autophagic proteolysis in cultured hepatocytes of fetal and suckling rats (13). The portal concentration of insulin increased 4-fold during development. A well known effect of insulin is its stimulation of protein synthesis and its inhibition of protein breakdown $(1,6,10,56)$.

An overnight fasting period induced a similar negative hepatic nitrogen balance (to approximately $65-70 \%$ of the prefasting protein content) in all age groups studied. The fasting state was confirmed by the virtual disappearance of hepatic glycogen and by the decrease in the concentration of circulating glucose. Despite the consistent effect of fasting on protein balance, the responses to this challenge of the different parameters that we studied were highly characteristic for each of the age groups studied. Hepatocellular volume decreased to $65-70 \%$ of prefasting values in all age groups studied. As argued, approximately $10 \%$ of this decrease in cell volume resulted from a loss of glycogen and protein content, so that cell volume as a direct result of fasting actually decreased $20-25 \%$. Circulating insulin concentrations decreased to $10-$ $25 \%$ of prefasting levels in all age groups. On the other hand, 
circulating glucagon concentrations strongly responded with a decrease to $40-60 \%$ of prefasting levels in perinatal and suckling animals, but this response had become markedly blunted at weaning and had disappeared in adult animals. Similarly, the concentration of many amino acids in plasma and liver strikingly decreased in the two younger age groups upon fasting, but the response had largely disappeared at weaning and was no longer noticeable in the adult. Our developmental analysis of the physiologic responses to an overnight fasting period therefore revealed that, irrespective of age, this challenge always resulted in a coordinate response of insulin and hepatocellular volume (both parameters strongly decreasing in all age groups) as well as in a coordinate response of glucagon and amino acid concentration in the liver and the circulation (both parameters decreasing in perinatal and suckling animals, but no longer at and after weaning). Interestingly, fasting therefore prematurely induces the concentration of amino acids in fetal and suckling rats to decrease to near-adult levels, i.e. to levels that are permissive in vitro for induction of proteolysis $(13,22)$. Assuming that the mechanism underlying short-term regulation of the hepatic protein balance does not change with development, our findings suggest that a decrease in the circulating concentration of insulin and/or a decrease in hepatocellular volume are more likely candidates as short-term physiologic stimulators of a negative hepatic nitrogen balance than changes in the concentration of circulating glucagon and/or amino acids. This view is indirectly supported by the observation that in adult rabbits, even after a prolonged fast $(8$ $\mathrm{d})$, the concentrations of amino acids in liver and plasma did not change (53).

Of the factors studied by us, only changes in the concentration of circulating insulin and the volume of hepatocytes were therefore consistently associated with a decrease in liver protein content upon a short-term fast. These data, in combination with data from the literature (see the Introduction), are compatible with a key role for insulin and cell volume in the regulation of the hepatocellular protein content. The observation that high concentrations of circulating insulin could not prevent a catabolic state in the glucose-supplemented fetuses, in which the hepatocellular volume had decreased markedly, may indicate that cell volume is a more important factor than insulin, at least at this stage of development. Interestingly, such a dissociation between circulating insulin levels and cell volume was seen only in the glucose-supplemented fetuses, as in the older animals high insulin levels were always associated with a large cell volume.

According to the literature, hepatic protein synthesis in fetal $(57,58)$ and particularly in suckling rats $(59,60)$ is more sensitive to fasting than protein breakdown. During further development the effects of fasting on hepatic protein synthesis decline $(59,60)$ and have virtually disappeared in adult rats. At the same time, the effects of fasting on the rate of protein degradation increase $(2,54,61)$. Although our study cannot discriminate between the effects of fasting on protein synthesis and degradation, our findings unequivocally show that, for a rapid growth of the liver, suckling animals have to be indeed fed around-the-clock.
Acknowledgments. We would like to thank Drs. A. F. M. Moorman and L. Boon for helpful and critical discussions, G. M. van Woerkom for his technical assistance with the amino acid analysis, W. Thornton for the insulin and glucagon assays, and $\mathrm{C}$. Hersbach for his assistance with the preparation of the figures.

\section{REFERENCES}

1. Mortimore GE, Pösö AR, Lardeux BR 1989 Mechanism and regulation of protein degradation in liver. Diabetes Metab Rev 5:49-70

2. Waterlow JC, Garlick PJ, Millward DJ 1978 The effects of nutrition and hormones on protein turnover in the liver. In: Waterlow JC, Garlick PJ, Millward DJ (eds) Protein Turnover in Mammalian Tissues and in the Whole Body. North-Holland, Amsterdam, pp 697-746

3. Martin-Requero A, de la Vega P, Martínez-Izquierdo JA, Parrilla R, Ayuso-Parrilla MS 1981 Insulin-glucagon interaction in the regulation of hepatic protein synthesis in the rat in vivo. Mol Physiol 1:35-44

4. Ayuso-Parrilla MS, Martin-Requero A, Pérez-Diaz J, Parrilla R 1976 Role of glucagon on the control of hepatic protein synthesis and degradation in the rat in vivo. J Biol Chem 251:7785-7790

5. Conde RD, Scornik OA 1976 Role of protein degradation in the growth of livers after a nutritional shift. Biochem J 158:385-390

6. Poli A, Gordon PB, Schwarze PE, Grinde B, Seglen PO 1981 Effects of insulin and anchorage on hepatocytic protein metabolism and amino acid transport. J Cell Sci 48:1-18

7. Draznin B, Trowbridge M 1982 Inhibition of intracellular proteolysis by insulin in isolated rat hepatocytes. J Biol Chem 257:11988-11993

8. Pfeifer U, Bertling J 1977 A morphometric study of the inhibition of autophagic degradation during restorative growth of liver cells in rat re-fed after starvation. Virchows Arch Cell Pathol 24:109-120

9. Hutson NJ, Mortimore GE 1982 Suppression of cytoplasmic protein uptake by lysosomes as the mechanism of protein regain in livers of starved-refed mice. J Biol Chem 257:9548-9554

10. Pfeifer U 1978 Inhibition by insulin of the formation of autophagic vacuoles in rat liver. J Cell Biol 78:152-167

11. Hopgood MF, Clark MG, Ballard FJ 1977 Inhibition of protein degradation in isolated rat hepatocytes. Biochem J 164:399-407

12. Seglen PO, Gordon PB 1984 Amino acid control of autophagic sequestration and protein degradation in isolated rat hepatocytes. J Cell Biol 99:435-444

13. Blommaart PJE, Zonneveld D, Meijer AJ, Lamers WH 1993 Effects of intracellular amino acid concentrations and hormones on lysosomal proteolysis in primary cultured perinatal rat hepatocytes. J Biol Chem 268:1610-1617

14. Sommercorn JM, Swick RW 1981 Protein degradation in primary monolayer cultures of adult rat hepatocytes. J Biol Chem 256:4816-4821

15. Hopgood MF, Clark MG, Ballard FJ 1981 Stimulation by glucocorticosteroids of protein degradation in hepatocyte monolayers. Biochem J 196:33-40

16. Horn J, Stern MD, Young M, Noakes DE 1983 Influence of insulin and substrate concentration on protein synthetic rate in fetal tissues. Res Vet Sci 35:35-41

17. May ME, Buse MG 1989 Effects of branched-chain amino acids on protein turnover. Diabetes Metab Rev 5:227-245

18. Proud SG 1994 Turned on insulin. Nature 371:747-748

19. O'Brien C 1994 Missing link in insulin's path to protein production. Science 266:542-543

20. Ballard FJ, Wong SSC, Knowles SE, Partridge NC, Martin TJ, Wood CM, Gunn JM 1980 Insulin inhibition of protein degradation in cell monolayers. J Cell Physiol 105:335-346

21. Häussinger D, Lang F 1991 Cell volume in the regulation of hepatic function: a mechanism for metabolic control. Biochim Biophys Acta 1071:331-350

22. Meijer AJ, Gustafson LA, Luiken JJFP, Blommaart PJE, Caro LHP, van Woerkom GM, Spronk C, Boon L 1993 Cell swelling and the sensitivity of autophagic proteolysis to inhibition by amino acids in isolated rat hepatocytes. Eur $\mathbf{J}$ Biochem 215:449-454

23. Conde RD, Scornik OA 1977 Faster synthesis and slower degradation of liver protein during developmental growth. Biochem J 166:115-121

24. Bergmeyer HU 1970 Methoden der enzymatischen Analyse. Verlag Chemie, Weinheim

25. Lust WD, Passonneau JV, Crites SK 1975 The measurement of glycogen in tissues by amylo- $\alpha-1,4-1,6$-glucosidase after the destruction of preexisting glucose. Anal Biochem $68: 328-331$

26. Williamson JR, Corkey BE 1969 Assays of intermediates of the citric acid cycle and related compounds by fluorometric enzyme methods. Methods Enzymol 13:434-513

27. Burton K 1956 A study of the conditions and mechanism of the diphenylamine reaction for the colorimetric estimation of deoxyribonucleic acid. Biochem $\mathbf{J} 62: 315-$ 323

28. Faloona GR, Unger RH 1974 In: Faloona GR, Unger RH (eds) Methods of Hormone Radioimmunoassay. Academic Press, New York, pp 317-330

29. Lamers WH, Mooren PG 1980 Role of glucocorticosteroid hormones on the levels of rat liver carbamoylphosphate synthetase (ammonia) and arginase activity during ontogenesis. Biol Neonate 37:113-137

30. Rohr HP, Wirtz A, Henning LC, Riede UN, Bianchi L 1971 Morphometric analysis of the rat liver cell in the prenatal period. Lab Invest 24:128-139 
31. Greengard O, Federman M, Knox WE 1972 Cytomorphometry of developing rat liver and its application to enzymic differentiation. J Cell Biol 52:261-272

32. Knox WE 1976 Enzyme Patterns in Fetal, Adult and Neoplastic Rat Tissues. S. Karger, Basel

33. Girard JR, Cuendet GS, Marliss EB, Kervan A, Rieutort M, Assan R 1973 Fuels, hormones and liver metabolism at term and during the early postnatal period. J Clin Invest 52:3190-3200

34. Beaudry MA, Chiasson JL, Exton JH 1977 Gluconeogenesis in the suckling rat. Am J Physiol 233:E175-E180

35. Di Marco PN, Oliver TI 1978 Adenosine $3^{\prime}: 5^{\prime}$-monophosphate in perinatal rat liver. Eur J Biochem 87:235-241

36. Remesar X, Arola L, Palou A, Alemany M 1980 Plasma amino-acid concentrations during development in the rat. Arch Int Physiol Biochim 88:443-452

37. Shotwell MA, Kilberg MS, Oxender DL 1983 The regulation of neutral amino acid transport in mammalian cells. Biochim Biophys Acta 737:267-284

38. Kilberg MS 1986 System A-mediated amino acid transport: metabolic control at the plasma membrane. Trends Biochem Sci 11:183-186

39. Meijer AJ, Lamers WH, Chamuleau RAFM 1990 Nitrogen metabolism and ornithine cycle function. Physiol Rev 70:701-748

40. Leoni S, Spagnuolo S, Dini I, Conti Devirgiliis I 1987 Regulation of amino acid transport in isolated rat hepatocytes during development. J Cell Physiol 130:103-110

41. Bellemann P 1981 Amino acid transport and rubidium-ion uptake in monolayer cultures of hepatocytes from neonatal rats. Biochem J 198:475 483

42. Bellemann P 1981 Enhanced amino acid transport in cultured hepatocytes during liver development. J Biochem 90:1821-1824

43. Martinez-Mas JV, Casado J, Felipe A, Marin JJG, Pastor-Anglada M 1993 L-Alanine uptake by rat liver parenchymal and haematopoietic cells during the perinatal period. Biochem J 293:819-824

44. Snell K 1982 Protein, amino acid and urea metabolism in the neonate. In: Jones CT: (ed) Biochemical Development of the Fetus and the Neonate. Elsevier Biomedical Press, Amsterdam

45. Oliver IT, Ballard FJ, Shield J, Bentley PJ 1962 Liver growth in the early postpartum rat. Dev Biol 4:108-116

46. Gaussin V, Baquet A, Hue L 1992 Cell shrinkage follows, rather than mediates, the short-term effects of glucagon on carbohydrate metabolism. Biochem J 287:17-20

47. Fenn WO 1939 The deposition of potassium and phosphate with glycogen in rat livers. J Biol Chem 128:297-307
48. Girard JR, Guillet I, Marty J, Marliss EB 1975 Plasma amino acid levels and development of hepatic gluconeogenesis in the newborn rat. Am J Physiol 229:466473

49. James J, Bosch KS, Fronik GM, Houtkooper JM 1986 Naphthol-yellow-S protein content of individual rat hepatocytes as related to food intake and short-term starvation. Cell Tissue Res 243:165-169

50. Belloni AS, Rebuffat P, Gottardo G, Meneghelli V, Coi A, Mazzocchi G, Nussdorfer GG 1988 A morphometric study of the effects of short-term starvation on rat hepatocytes. J Submicrosc Cytol Pathol 20:751-757

51. Baccino FM, Tessitore L, Cecchini G, Messina M, Zurettl MF, Bonelli G, Gabriel L, Amenta JS 1982 Control of cell protein catabolism in rat liver. Biochem J 206:395405

52. Casado J, Remesar X, Pastor-Anglada M 1987 Hepatic uptake of amino acids in late-pregnant rats: effect of food deprivation. Biochem J 248:117-122

53. Yap SH, Hafkenscheid JCM 1981 Effect of starvation on the synthesis rate of albumin in vivo and its relation to the concentrations of amino acids in the peripheral blood, the portal circulation and in the liver cytosolic fraction. Ann Nutr Metab 25:158-164

54. Agius L 1991 What determines the increase in liver cell volume in the fasted-to-fed transition: glycogen or insulin? Biochem $\mathrm{J} 226: 843-845$

55. Flakoll PJ, Borel MJ, Wentzel LS, Williams PE, Lacy DB, Abumrad NN 1994 The role of glucagon in the control of protein and amino acid metabolism in vivo. Metabolism 43:1509-1516

56. Parrilla R, Goodman MN, Toews CJ 1974 Effect of glucagon: insulin ratios on hepatic metabolism. Diabetes 23:725-731

57. Johnson JD, Dunham T, Skipper BJ, Loftfield RB 1986 Protein turnover in tissues of the rat fetus following maternal starvation. Pediatr Res 20:1252-1257

58. Johnson JD, Dunham T 1988 Protein turnover in tissues of the fetal rat after prolonged maternal malnutrition. Pediatr Res 23:534-538

59. Vavrousek-Jakuba EM, Miller SA 1975 Effect of starvation on protein synthesis in neonatal rat liver. J Neurochem 105:1326-1333

60. Burrin DG, Davis TA, Fiorotto ML, Reeds PJ 1992 Hepatic protein synthesis in suckling rats: effects of stage of development and fasting. Pediatr Res 31:247-252

61. Garlick PJ, Millward DJ, James WPT, Waterlow JC 1975 The effect of protein deprivation and starvation on the rate of protein synthesis in tissues of the rat. Biochim Biophys Acta 414:71-84 